8. Sharifian F. Cultural conceptualisations in learning English as an L2: Examples from Persian-speaking learners. Iranian Journal of Language Teaching Research. 2013. 1(1): 90-116.

DOI https://doi.org/10.30525/978-9934-26-110-7-76

\title{
МІЖКУЛЬТУРНА КОМУНІКАЦІЯ ЗМІНИ У ВИКОРИСТАННІ УГОРСЬКОЇ МОВИ ЗА КОРДОНОМ
}

\author{
Нодь Н. Й. \\ кандидат філологічних наук, \\ доиент кафедри угорської філологіі \\ Ужгородський національний університет \\ м. Ужггород, Украӥна
}

Мовна мінливість означає, що даний мовний елемент може виражатися в різних варіаціях і, отже, у тісно пов'язаних між собою мовних варіантах. Іншими словами, жодна людина 3 однаковою рідною мовою не могла б завжди говорити одне і те ж за однакових обставин [1, с. 12-25.]. Відмінності випливають насамперед із середовища та громади, де вони виростають. Дослідження Леслі та Джеймса Мілрой у Белфасті першими довели, що коли члени мають набагато більше контактів між собою, ніж із сторонніми, поведінка членів визначається більш сильними нормами, а повага до власних норм стає дуже сильною. [3, с. 19-36.] Результати показують, що якщо хтось інтенсивніше інтегрується у своє співтовариство, він буде використовувати більше нестандартних версій, характерних для цієї групи. Один із результатів, досягнутий Пітером Трудгіллом з Нориджа, продемонстрував, що хоча оцінка версії стандартної мови є безсумнівною, досліджувані громади прив'язані до своєї мовної версії, навіть якщо вони вже зазнали негативної дискримінації. [4, с. 43-54.] Метою дослідження є пошук характеристик, що характеризують вживання мови молодшої людини, яка переїхала до Угорщини. Розширення дослідження на більше транскордонної інформатики, ніж у попередньому дослідженні, і доповнення існуючих даних особистими життєвими історіями, індивідуальним досвідом, поясненнями, розповідями та звітами про життєвий шлях. Ми вважаємо важливим спостерігати за мовними явищами, які висунулися на перший план під час інформативного мовленнєвого досвіду в Угорщині, та в рамках подальшого дослідження, щоб підкреслити, чи 
існує взаємозв'язок між мовними установками та професійним шляхом. В ході нашого дослідження ми поговоримо з угорськомовними студентами, які проживали у своїй країні до кінця середньої школи, середньої школи (гімназіі), а потім переїхали до Угорщини, щоб продовжити навчання.

Якісний метод підкреслює відгуки, з якими стикається іноземний студент під час перебування в Угорщині. Студенти у віці 18-25 років говорять про свої особисті життєві історії та індивідуальний досвід, а не, між іншим, про діалектичні характеристики інформаторів.

„Поняття мовної норми в сучасному угорському культивуванні мови базується на тому уявленні, що у мові, та відповідно у іiі різноманітних варіантах, існують такі мовні форми (слова, словосполучення, граматичні структури, рішення порядку слів, граматичні та фонетичні правила, відтінки тонів тощо), які за своєю суттю кращі або гірші за інші, не залежно від контексту використання» - можна прочитати у праці Іштвана Ланштяка. [2, с. 118]. У світлі цього пояснення респонденти висловлювалися про те, чи на їхню думку угорці, що мешкають на території Угорщини, у більшості правильно чи неправильно розмовляють угорською мовою. Виходячи з більшості відповідей, не вдалося виявити великої різниці між мовою тих угорців, що мешкають на території Угорщини та власною мовою респондента, і респонденти оцінили обидві мовні версії однаково правильними та красивими $(44,3 \%)$. $27,1 \%$ респондентів вважають, що хоча використання мови тими угорцями, що мешкають на території Угорщини не можна вважати неправильним, все ж таки воно помітно відрізняється від закордонних угорських мовних версій. Ще 21,4\% вважають, що угорці, які мешкають на території Угорщини, розмовляють невибагливо, а 7,1\% респондентів вважають, що угорці, які мешкають на території Угорщини, розмовляють нею безумовно неправильно. Цікаво, що $80 \%$ тих, хто вважає неправильним використання мови мешканцями столиці, - чоловіки. Питання використання мови полягає в тому, чи не зазнали респонденти якихось змін у користуванні мовою після переїзду. На думку $67,1 \%$ респондентів, їхня мова змінилася лише незначно порівняно з початковою, і вона все ще має свої основні риси. Виходячи з відповідей, 27,1\% респондентів сказали, що вживання ними мови суттєво змінилося за час перебування у столиці, що не $є$ неочікуваним результатом, якщо брати до уваги, наслідки мовної гнучкості, яка випливає із віку респондентів. Всього лише 4 респондентів вважають, що їхнє мовлення зовсім не змінилося 3 часу переселення, вони складають 5,7 \%. Це особи жіночого роду та переважно закарпатського походження. 
Ti, хто зазнали змін у використанні власної мови, змогли надати інформацію про те, як виявляються сприйняті ними зміни в мові, відповівши на наступні запитання. Один респондент міг позначити i кілька відповідей. Могли обирати серед наступних:

- використовую нові слова, вирази

- на ті самі вирази використовую інші слова

- змінилася моя інтонація

- змінилася моя вимова

- інше

Виходячи 3 отриманих відповідей, 41 респондент зазнав змін словникового запасу у своєму мовленні: вживають нові слова та вирази, значно збагатився їхній словниковий запас $(61,2 \%)$. Інші 32 респондентів, тобто 47,8\% відзначили, що стосовно тих самих виразів вже використовують інші слова, ніж до того. Серед інших відповідей виділяємо наступні:

3 різних причин щораз більше молоді переселяється в столицю Угорщини, сподіваючись на навчання чи краще життя. Переселенці не потрапляють у проблемне становище через своє походження чи мовне вживання, проте $\epsilon$ й невеликий відсоток відмінних від цього випадків. Угорці, які проживають на території Угорщини часто вважають дивним слововживання закордонних угорців, проте не залежно від цього не виправляють, та не висміюють його. Мову інших потрібно поважати, як іноземну мову, так і варіант даної мови!

Ключові слова: мова, мінливість, молодша людина, діалектичні характеристики, якісний метод.

\section{Література:}

1. Bárczi Géza. A „pesti nyelv» [The „language of Pest»]. Budapest: Kiadja a Magyar Nyelvtudományi Társaság. 1932. P. 12-25.

2. Lanstyák István. Nyelvhelyesség. //Hungarológia. Szerkesztette: Beke Zsolt, Lanstyák István és Misad Katalin. - Pozsony/Bratislava: Stimul, 2010.

3. Milroy, James -Milroy, Lesley. Belfast: change and variation in an urban vernacular. Szerk.: Trudgill, P. Sociolinguistic patterns in British English. London: Arnold, 1978. P. 19-36.

4. Tolcsvai Nagy Gábor. A nyelvi közösség és a nyelvi egység, kisebbségben. http://adatbank.transindex.ro/html/alcim_pdf11057.pdf The linguistic community and linguistic unity, in a minority 